\title{
8. THE IMPLICATIONS OF FRACTURE AND VOID DISTRIBUTION FROM BORE-HOLE TELEVIEWER IMAGERY FOR THE SEISMIC VELOCITY OF THE UPPER OCEANIC CRUST AT DEEP SEA DRILLING PROJECT HOLES 501 AND 504B'
}

\author{
Roger N. Anderson, Lamont-Doherty Geological Observatory and Department of Geological Sciences, \\ Columbia University, Palisades, New York \\ and \\ Mark D. Zoback, United States Geological Survey, Menlo Park, California
}

\begin{abstract}
To examine closely in situ lithostratigraphy and the distribution of fracture and void zones in oceanic Layer $2 \mathrm{~A}$, a comprehensive survey of Deep Sea Drilling Project Holes 501 and 504B on the south flank of the Costa Rica Rift was conducted with an ultrasonic bore-hole televiewer. The televiewer records clearly outline the stratigraphic interrelationship between pillow basalts and massive flows, as well as the natural fracture distribution and void- and clay-zeolite-rich zones. A direct correlation is found between low-velocity intervals on the ultrasonic velocity logs and fracture and void zones. The ultrasonic velocity appears to be a good indicator of the composition of materials filling cracks and voids in the upper oceanic crustal Layer $2 \mathrm{~A}$. At the top of the basement, massive flow units and large pillow zones are interrupted with fractures and voids filled at least by a 2:1 ratio of sea water to clay, whereas at a sub-basement depth of 100 to 200 meters small pillow flow units are interfilled with at least a 2:1 ratio of clay and zeolite to sea water. The increase with depth in the degree to which clay and zeolite fill fractures and voids likely explains the increase in seismic velocity as Layer $2 \mathrm{~A}$ merges into $2 \mathrm{~B}$ with depth in the oceanic crust, as well as the order-of-magnitude drop in permeability observed in Hole 504B.
\end{abstract}

\section{INTRODUCTION}

Heat-flow measurements on the flanks of mid-ocean ridges record a transition from convective heat transfer near ridge axes to predominantly conductive heat flow in old ocean basins (Anderson et al., 1977). This transition in the heat-transfer mechanism is mirrored in an increase in seismic velocity of the upper 500 meters of the oceanic crust, to the point that Layer $2 \mathrm{~A}$ (with characteristic velocities ranging from 2 to $5 \mathrm{~km} / \mathrm{s}$ ) essentially "disappears" on the flanks of mid-ocean ridges (Houtz and Ewing, 1976). In order to investigate possible interrelationships between these major changes in the oceanic crust, we participated in an integrated suite of in situ down-hole experiments at DSDP Holes 501 and 504B, on the south flank of the Costa Rica Rift of the Galapagos Spreading Center (Fig. 1). The experiments included permeability and pore-pressure measurements (Zoback and Anderson, this volume), sonic velocity logging (Cann and Von Herzen, this volume), and formation-fluid sampling (Mottl et al., this volume). In this paper, we report ultrasonic bore-hole televiewer imagery that was acquired to examine the lithostratigraphy and fracture variation with depth in Layer 2A. The studies in these drill holes are only a starting point for the examination of the evolution in physical properties away from mid-ocean ridges, but they yield fascinating insights into the structure and permeability of the shallow oceanic crust and the factors controlling seismic velocity and its increase with depth and age.

${ }^{1}$ Cann, J. R., Langseth, M. G., Honnorez, J., Von Herzen, R. P., White, S. M., et al., Init. Repts, DSDP, 69: Washington (U.S. Govt. Printing Office).
One of the primary difficulties with interpretation of the lithostratigraphy of the oceanic crust using deep-sea drilling results from the D/V Glomar Challenger has been the low percentage of core recovery. The drilling operations crush and wash away an average of $70 \%$ of all drilled-oceanic crust. Previously, the only measurements over entire drill holes were geophysical logs, but it has been extremely difficult to interpret geophysical observations, because of lack of comparable examples on land for correlations. That is, most geophysical logging techniques have been used very rarely in volcanic terranes on land (much less in alternating layers of altered pillow and flow basalts). Thus, geophysical logs from deep-sea drill holes have been difficult to correlate with specific structural and stratigraphic relationships in the oceanic crust.

\section{THE BORE-HOLE TELEVIEWER}

A seldom-used logging tool developed by Mobil Oil Corp. has been used in this study to provide the data needed to interpret more fully the structure and stratigraphy of the ocean crust as well as results of geophysical logging in deep-sea drill holes. With the support of Amoco Oil Field Research, we deployed a bore-hole televiewer (BHTV) in Holes 501 and 504B on DSDP Legs 68 and 69 on the south flank of the Costa Rica Rift of the Galapagos Spreading Center (Fig. 1).

The BHTV contains a transducer which rotates three times per second and emits a $1-\mathrm{mHz}$ pulse 180 times per second as the tool is moving up- or down-hole at $0.6 \mathrm{me}$ ters per minute. By displaying the amplitude of the acoustic pulse reflected off the wall of the hole (referenced to magnetic north), the image produced by the 


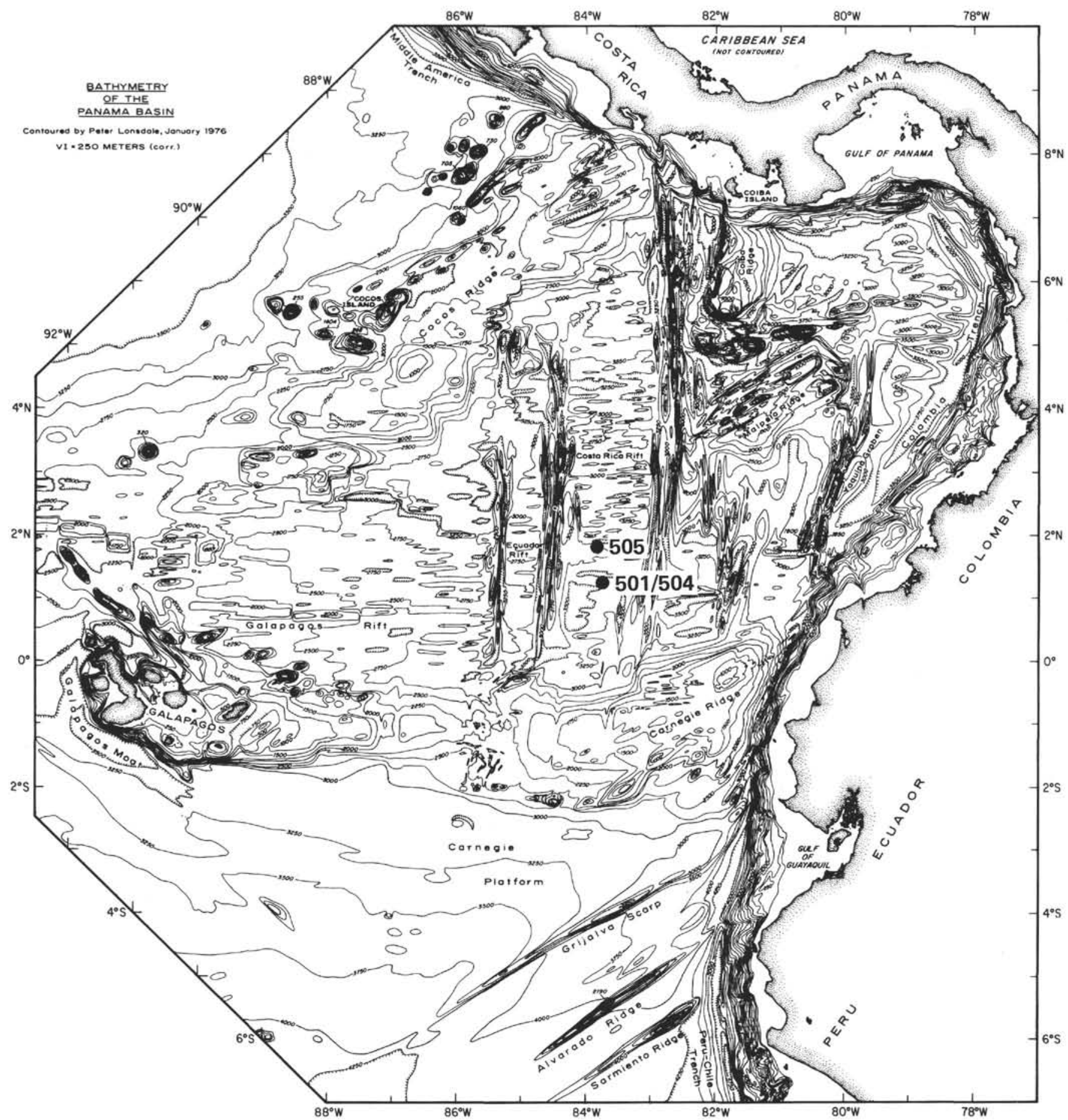

Figure 1. Location of DSDP Sites 501, 504, and 505 on the south flank of the Costa Rica Rift, easternmost segment of the Galapagos Spreading Center.

BHTV is that of the reflectivity and smoothness of the hole. The result is a complete north-to-north "picture" of the circumference of the hole (Fig. 2). Hard, smooth surfaces produce strong reflections, or "white-zones"; soft clays, fractures, and voids absorb most of the signal, producing "dark zones" on the records. Similarly, where the hole reaches great width, and no appreciable reflection is returned, "dark zones" appear.

\section{THE SETTING}

Holes 501 and 504B are within $1 \mathrm{~km}$ of each other in 6.1-m.y.-old sea floor on the southern flank of the Costa Rica Rift, the easternmost spreading segment of the Galapagos Spreading Center (Fig. 1). The sites were chosen to penetrate into young oceanic crust with high surface heat flow. Because the holes are near the Equa- 

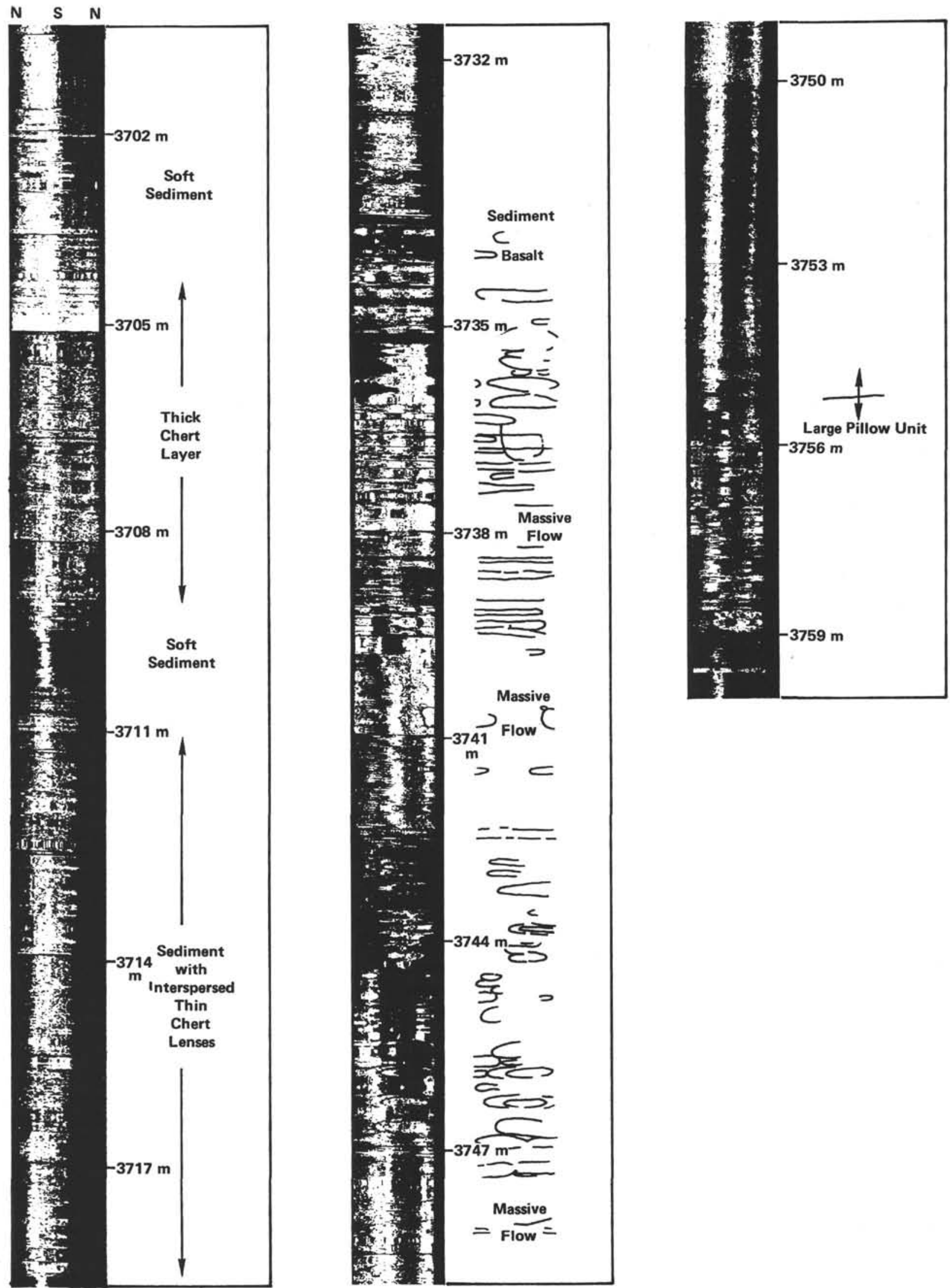

Figure 2. Bore-hole televiewer imagery of the well bore at Site 501. Horizontal exaggeration is 3:1. The horizontal axis is north-to-north dissection of the hole. White is strong reflectance. Black is no reflectance. 
tor, 280 meters of pelagic sediments have formed an impermeable lid over a hydrothermal circulation system active in the oceanic crust (CRRUST, in press). Flow tests in the oceanic crust show that the permeability of Layer $2 \mathrm{~A}$ drops from 20 to 40 millidarcys (md) in the upper 100 meters to 2 to $4 \mathrm{md} 200 \mathrm{~m}$ below the sediment/basalt contact (Anderson and Zoback, 1982). Porepressure measurements and temperature logs show oceanic bottom water being drawn naturally into an underpressured aquifer with permeability of $200 \mathrm{md}$ located between 50 and 100 meters below the top of Layer $2 \mathrm{~A}$ (Becker et al., this volume). As will be shown below, sonic logs indicate an increase in velocity of Layer $2 \mathrm{~A}$ from 2.5 to $5 \mathrm{~km} / \mathrm{s}$ over the upper 200 meters of the oceanic crust (Cann and Von Herzen, this volume).

The BHTV contributes significantly to our understanding of why (1) the sedimentary layer forms a hydraulic lid, (2) the permeability drops by an order of magnitude with depth, and (3) the seismic velocity increases with depth. Additionally, we get the first complete glimpse of the lithostratigraphy of the upper oceanic crust.

\section{STRUCTURE AT HOLE 501}

Using a BHTV loaned to us for this experiment by Amoco Field Research Co., we logged the entire sedimentary column and 25 meters below the sediment/basalt contact in Hole 501 (Fig. 2). In much of the sedimentary section, the record is very dark (that is, there is no significant reflection from much of the circumferential sweep of the trace). This, we believe, is a result of the pronounced ellipticity of the hole; the problem is most severe at about 3710 meters depth.

Surprisingly, chert was encountered over the lower 30 meters of the sediment column. This was the "youngest" chert yet encountered by the Glomar Challenger (CRRUST, in press). The BHTV records show that the first encountered chert is a solid layer 5 meters in thickness. Below are interlayered lenses of chert and silicified limestone. The chert, being harder and thus resistant to "washing out," shows up as bright high-reflectance bands between the darker limestone layers. The chert fragments recovered by coring demonstrate the usefulness of BHTV records for stratigraphic interpretation: though nodular in form, the chert fragments frequently had one flat surface. Without the BHTV, fracturing along joints might have been suspected. Of course, we do not know the horizontal extent of these chert layers, except that all holes drilled at Sites 501 and 504 encountered chert over the basal $\mathbf{3 0}$ meters.

Pillow basalts show dramatically on the BHTV records as bright spots within dark ellipses, which are likely caused by glass and alteration rims fractured and washed out during drilling (Fig. 2). Several massive flow units are seen at the top of the oceanic crust, interlayered with the pillow basalt units. Because core recovery was only $29 \%$, the interrelationship between these two stratigraphic units is obscured by large voids in the hole where virtually no signal is reflected back to the transducer (e.g., at $3735 \mathrm{~m}$ in Fig. 2).
In addition to pillows, basaltic flows interlayered with the pillow units are seen clearly by the televiewer. One massive flow unit is 8 meters thick. This flow (from 3747 to 3755 m; Fig. 2) does not appear to have many fractures.

\section{BHTV STRUCTURES AT HOLE 504B}

On Leg 69, a United States Geological Survey BHTV was used to $\log 196$ meters below the casing, which was set 2 meters into basalt 380 meters below the sea floor in Hole 504B. The factory-equipped transducer was destroyed by a pressure-compensation failure on the first lowering of the tool. The hole then was logged using a $600-\mathrm{kHz}$ EDO-Western transducer array taken from an acoustic re-entry tool. Unfortunately, 60-cycle noise, apparently caused by a faulty logging cable, obscured the BHTV image. Because the noise has proved difficult to remove from the signal, we must present line drawings (Fig. 3), rather than the original records. Figure 4 shows an example of the data. Not only are distinct pillow and flow units discernible with the new transducer, but also contacts between distinct eruptive units can be seen clearly (e.g., 3855 m; Figs. 3 and 4). Fracture resolution is several millimeters, and several fractures this small can be seen (e.g., 3881 m; Fig. 4).

From the top of the logged basement section, thick flow units dominate the upper 50 meters of Layer $2 \mathrm{~A}$. These flows have numerous large-diameter fractures which are predominantly horizontal to sub-horizontal (Fig. 3). Thin interlayers of large-diameter pillow units are seen at $3757,3765,3773$ to $3778 \mathrm{~m}$, and 3782 meters. The 8-meter-thick massive flow unit of Hole 501 (3747$3755 \mathrm{~m}$ in Fig. 2) shows up $1 \mathrm{~km}$ away at Hole 504B, but is more broken. A 10-meter massive flow is seen at $\mathbf{3 7 8 5}$ to 3795 meters, and even small pits in the hole can be discriminated (3855 m; Fig. 4). From 3805 to 3825 meters, an anomalous low-reflectance zone exists. While structure can be seen within this zone, the amplitude of reflectance is much lower than in zones directly above and below.

Pillows gradually appear more often down-section, but their average size decreases from 20 to $30 \mathrm{~cm}$ near the basalt/sediment contact to smaller and smaller pillows. For example, from 3838 to 3851 meters a suite of pillows has a range in size from 0.5 to $30 \mathrm{~cm}$, whereas the pillows from 3890 to 3897 meters are each $<10 \mathrm{~cm}$ high. Also, flows become more common and are much thinner deeper in the section. The entire lower 55 meters of the recorded section appear as discrete pillows, each $<1$ meter in thickness (Fig. 3).

Fractures are more concentrated at the borders of separate pillow flows (e.g., $3915 \mathrm{~m}$; Fig. 3), but some zones are uniformly fractured; as in Hole 501, most fractures are horizontal to subhorizontal (e.g., 3890$3895 \mathrm{~m}$ ), and few steeply dipping vertical fractures are seen in the BHTV.

The general level of reflectance drops from flows to pillows and from the top to the bottom of the hole, probably reflecting the increased clay alteration that was clearly observed in the cores (CRRUST, in press). 


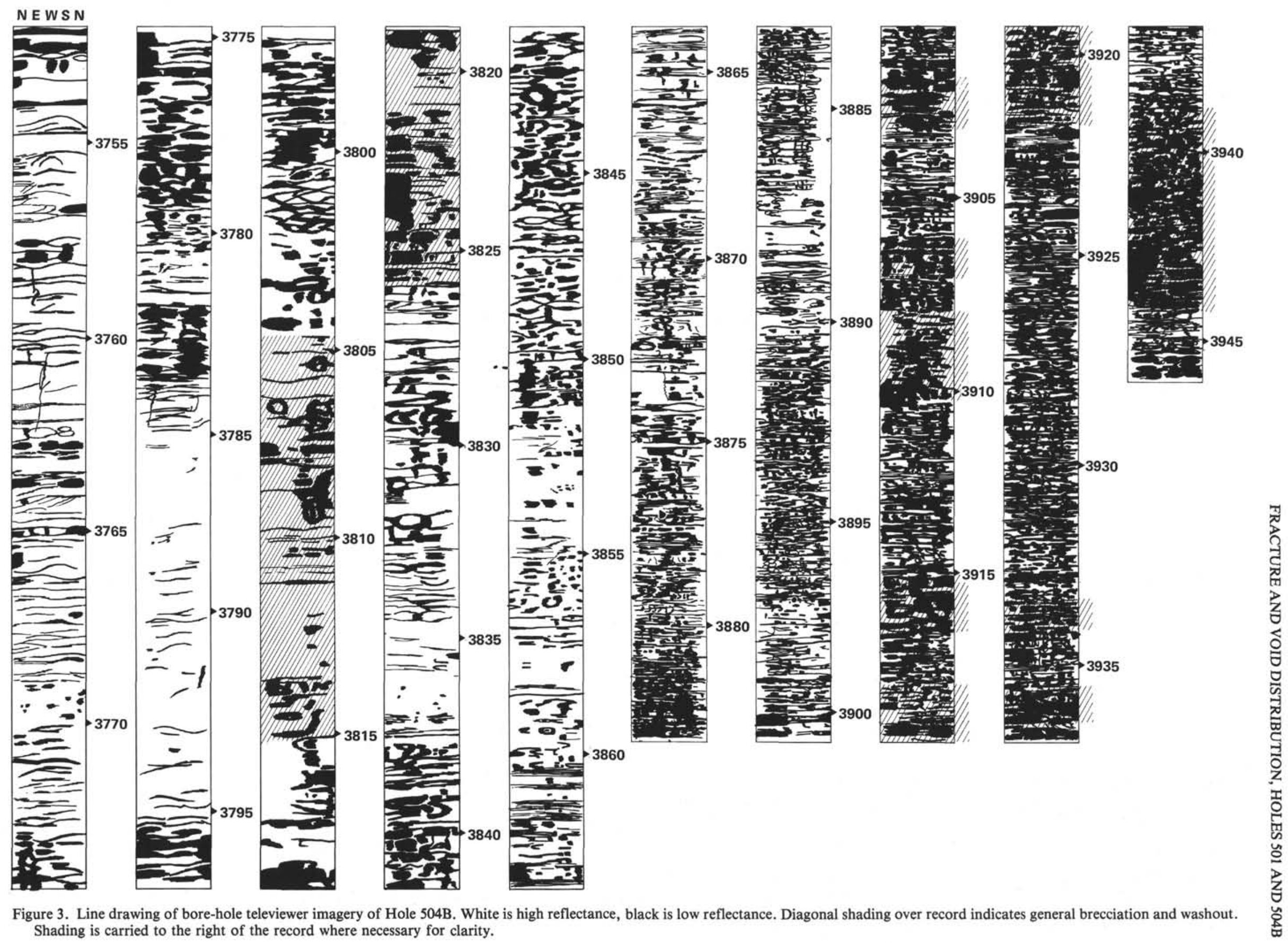




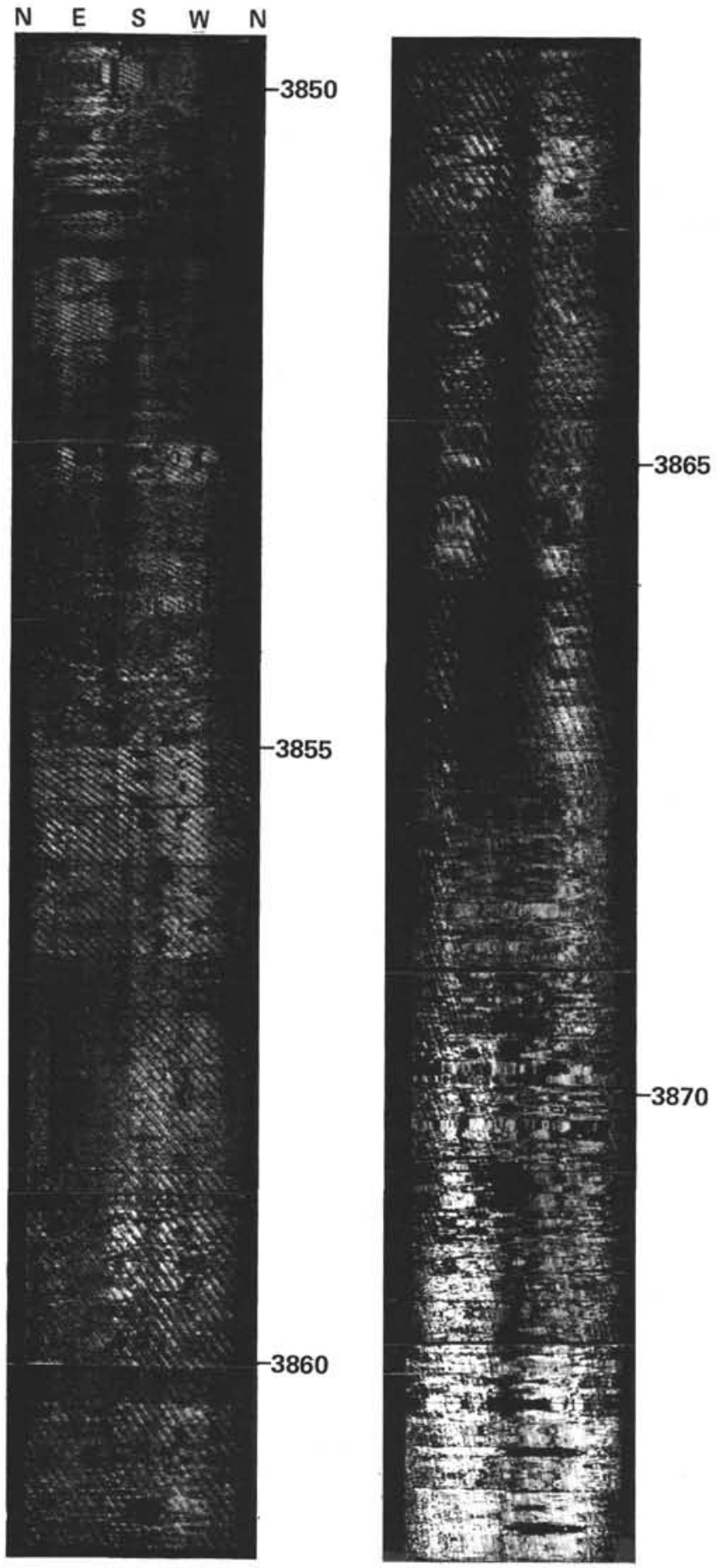

Figure 4. Actual images of Hole 504B BHTV log. Diagonal banding is unwanted cable noise.

\section{QUANTITATIVE ANALYSES}

One of the primary aims of this project is to improve the quantitative interpretive techniques of analysis of BHTV records, because we are concerned with the geophysical meaning of the fracture and structure variations seen down-hole in Holes 501 and 504B. Specifically, we wish to relate variations observed in the sonic- velocity $\log$ of Hole 504B to specific stratigraphic and structural variations seen with the BHTV.

Layer $2 \mathrm{~A}$ of the oceanic crust is a seismic transition from the low-velocity sediment $\left(V_{\mathrm{p}}<2 \mathrm{~km} / \mathrm{s}\right)$ above to the high-velocity basaltic Layer $2 \mathrm{~B}\left(V_{\mathrm{p}}>5 \mathrm{~km} / \mathrm{s}\right)$ below. This transition consists of a velocity gradient which occurs within the interlayered pillow flow and rubble zone where shallow volcanic extrusives are gradually replaced by intrusives. Layer $2 \mathrm{~A}$ can be seen clearly on the sonicvelocity log of Hole 504B (Fig. 5). Casing was set 10 meters into the crust. The velocity just below the casing begins at $\sim 2 \mathrm{~km} / \mathrm{s}$ and increases over the next $200 \mathrm{me}-$ ters to $\sim 5 \mathrm{~km} / \mathrm{s}$.

Several hypotheses have been presented to explain this velocity gradient. Each directly or indirectly implies that a change in elastic constants of basalt affects the compressional-wave velocity $\left(V_{\mathrm{p}}\right)$. In an isotropic, homogeneous, elastic medium, the compressional-wave velocity is defined as

$$
V_{\mathrm{p}}=\sqrt{\frac{k}{\varrho}+\frac{2 / 3 E}{(1+\sigma)}}
$$

where $k=$ bulk modulus $=1 /$ compressibility, $\varrho=$ density, $E=$ Young's Modulus, and $\sigma=$ Poisson's ratio.

\section{LABORATORY EXPERIMENTS}

On samples of oceanic crust retrieved near the MidAtlantic Ridge, Schreiber and Fox (1977) demonstrate that the existence of fractures and cracks lowers the elastic moduli, thereby lowering $V_{\mathrm{p}}$. As pressure was experimentally increased, these cracks closed, and the velocity increased to that approaching unfractured basalt. Schreiber and Fox (1977) also show that $V_{\mathrm{p}}$ is very sensitive to the degree of water saturation and pore-fluid pressure. Spudich and Orcutt (1980) further suggested that the increase in $V_{\mathrm{p}}$ with depth is caused directly by a decrease in pore pressure with depth in the upper oceanic crust. Hyndman and Drury (1976), Schreiber and Fox (1976), and Fox and Stroup (1981) argue that the highly fractured and perturbed nature of the upper oceanic crust results in low seismic velocity. Cracks, fissures, intercalated sediments, collapse pits, and rubble zones result in large-scale heterogeneity within the extrusive-intrusive transition, lowering its velocity. Additionally, or alternatively, Christensen and Salisbury (1972, 1975), Fox et al. (1973), and Schreiber and Fox $(1976,1977)$ suggested that an increased proportion of alteration minerals lowers the seismic velocity of basalt because clay replacing basalt has a lower seismic velocity $(4 \mathrm{~km} / \mathrm{s}$ versus $6 \mathrm{~km} / \mathrm{s})$. Christensen and Salisbury $(1972,1975)$ suggested that increased alteration with age decreases the seismic velocity of Layer 2, creating Layer 2A. However, later seismic techniques (e.g., Houtz and Ewing, 1976) showed that Layer $2 \mathrm{~A}$ begins immediately at the ridge axis, and that the velocity of this layer increases with age and depth into the oceanic crust. Schreiber and Fox $(1976,1977)$ therefore suggested that replacing sea water $\left(V_{\mathrm{p}}=1.5 \mathrm{~km} / \mathrm{s}\right)$ in voids with alteration minerals (smectite, chlorite, zeolite, calcite) causes the observed increase in velocity with age and depth. 

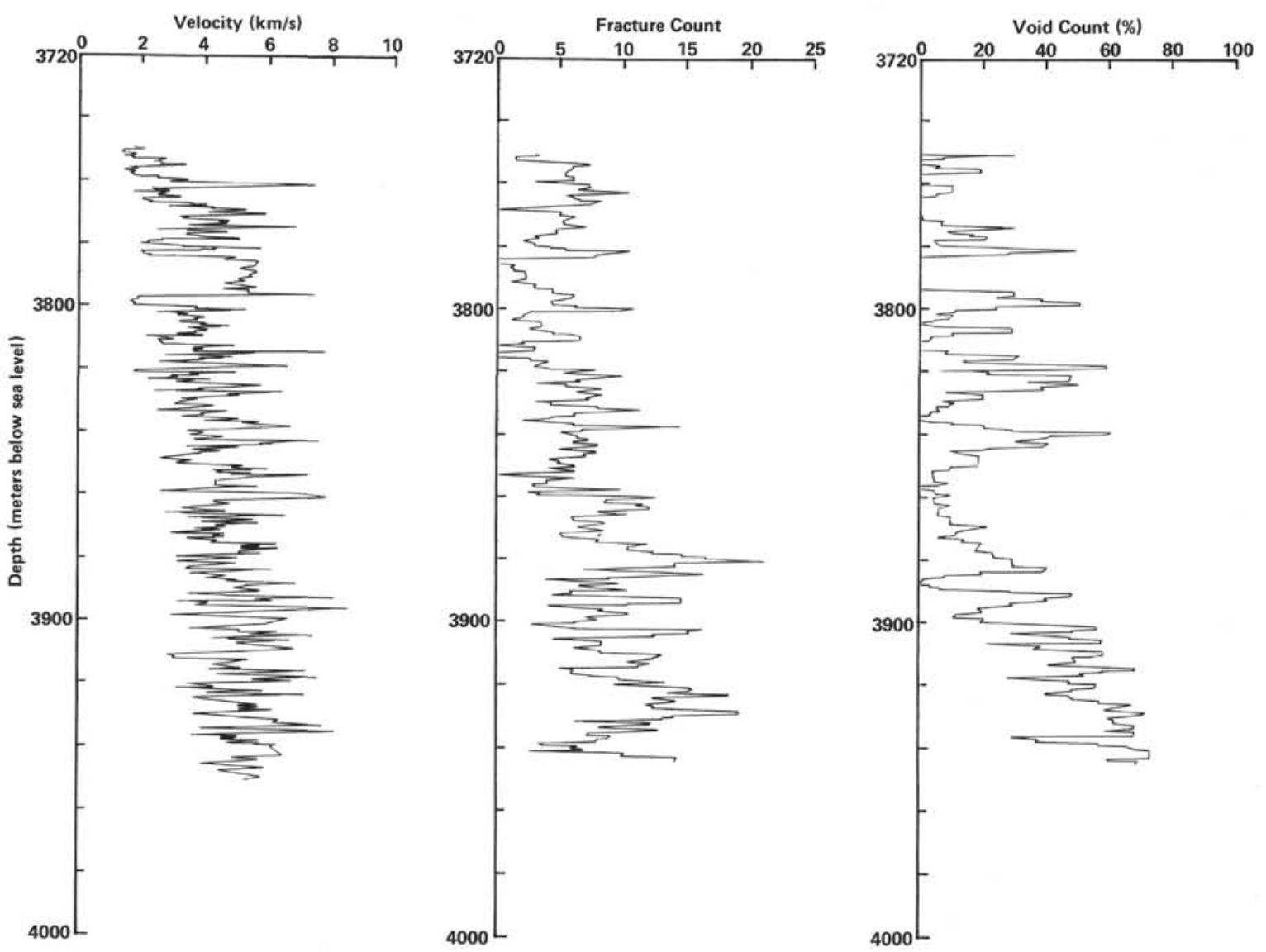

Figure 5. Sonic velocity of the upper 200 meters of basalt in Hole 504B corresponding to interval of BHTV log in Figure 3; fractures per meter; void count per meter (percent opacity of reflectance per meter).

The BHTV record of Hole 504B allows us to test these various hypotheses for the increase in seismic velocity with depth in Layer $2 \mathrm{~A}$, because we can see the change in character and structure of fracture and void reflections down the well bore.

\section{FRACTURE AND VOID COUNTS}

To this end, we counted the number of fractures observed on the BHTV records per meter in Hole 504B (Fig. 6A). We immediately see that the number of cracks significantly increases with depth, which would decrease the seismic velocity if the degree of fracturing were controlling $V_{\mathrm{p}}$ in Layer $2 \mathrm{~A}$. Instead, a marked velocity increase with depth is observed (Fig. 5). A cross-correlation plot of fracture count versus $V_{\mathrm{p}}{ }^{2}$ (Fig. 7A) shows (if anything) a crude but opposite correlation.

In addition to fracturing, we suspect that the structure of Layer $2 \mathrm{~A}$ is significantly controlled by what we term "voids." We prepared a plot of the percentage of voids in the hole (percent black versus white per meter; Fig. 3). Particularly in the pillow units, this "void count" (Fig. 5) measures the percent of pillow rims, glassy rind, and rubble surrounding the solid basaltic core of each interval. Presumably, the higher the void count, the lower the seismic P-wave velocity, but again an inverse correlation, if any, is seen down Hole 504B (Fig. 7B). Thus, despite an increase in fractures and voids with depth in the holes, an increase in $V_{\mathrm{p}}$ with depth is observed.

By summarizing fracture and void counts at each depth, we can examine whether the two different structural effects offset each other down-hole. This summation has no physical meaning, but was done to show the relative influence of the two variables. However, note that the number of fractures per meter apparently does not add to the percent voids per meter. Interestingly, high-intensity zones of fractures and voids are spaced every 10 to 15 meters in zones 0.5 to 5 meters thick (Figs. 5 and 7). Again, we see the unexpected result that increased fractures and voids correlate with increased $V_{\mathrm{p}}^{2}$.

Wishing to examine the influence of fracture and void variations within distinctive structural units, we divided the Hole 504B BHTV section into four stratigraphic types (Fig. 7): large-diameter pillows, small pillows, thick flows, and thin flows. We "de-skewed," or removed, the overall gradient in fracture plus void counts versus depth (Fig. 7) to see if the low-velocity troughs of the sonic $\log$ (also de-skewed in Fig. 7A) correspond to zones of high fracture + void count). If so, then the sonic log could be recording the velocity of material filling these fractures and voids, and we might then account for the change in Layer $2 \mathrm{~A}$ velocity with depth as a change in the velocity of crack- and voidfilling material. 

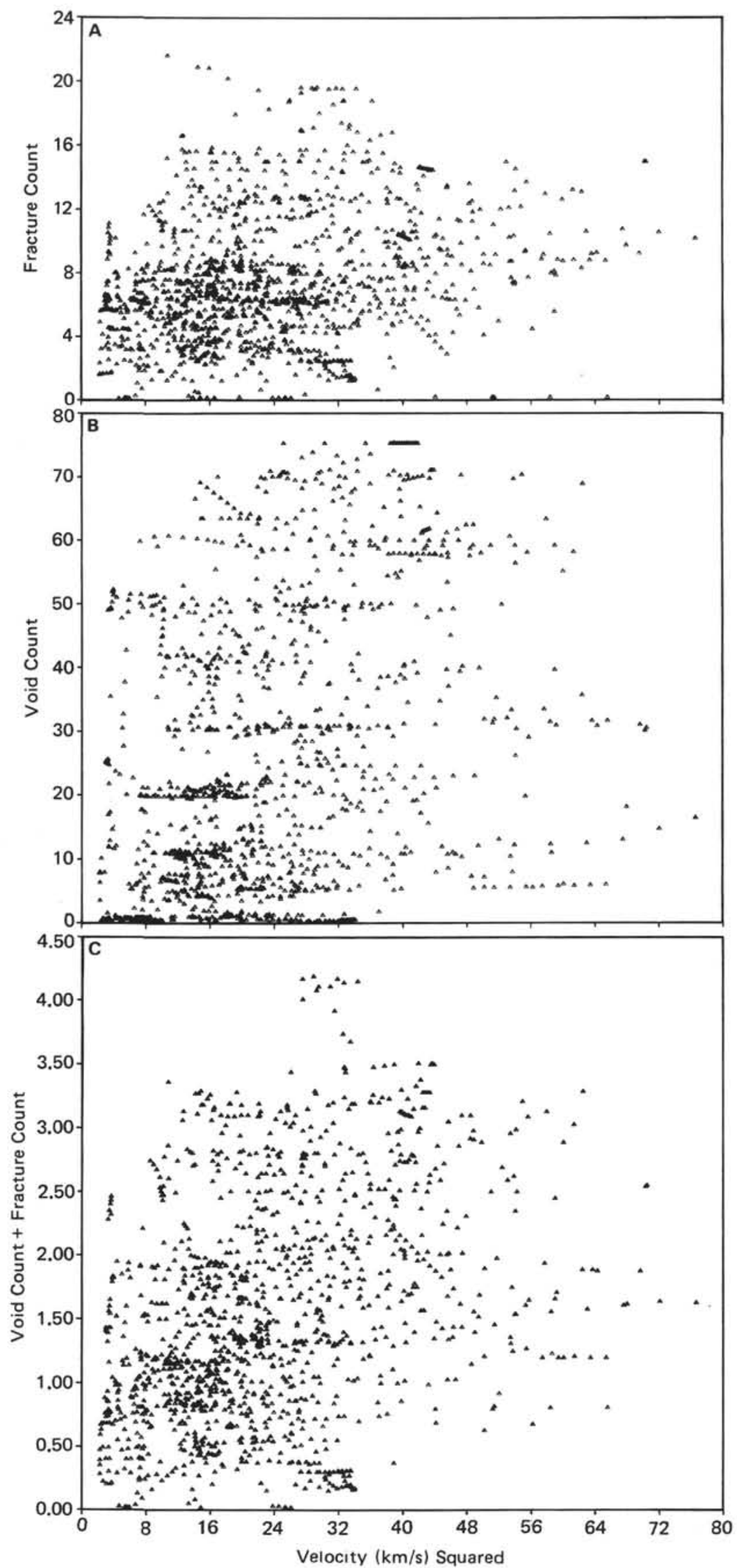

Figure 6. A. Velocity squared versus fracture count, Hole 504B. B. Velocity squared versus void count. C. Velocity squared versus the void count plus fracture count. 

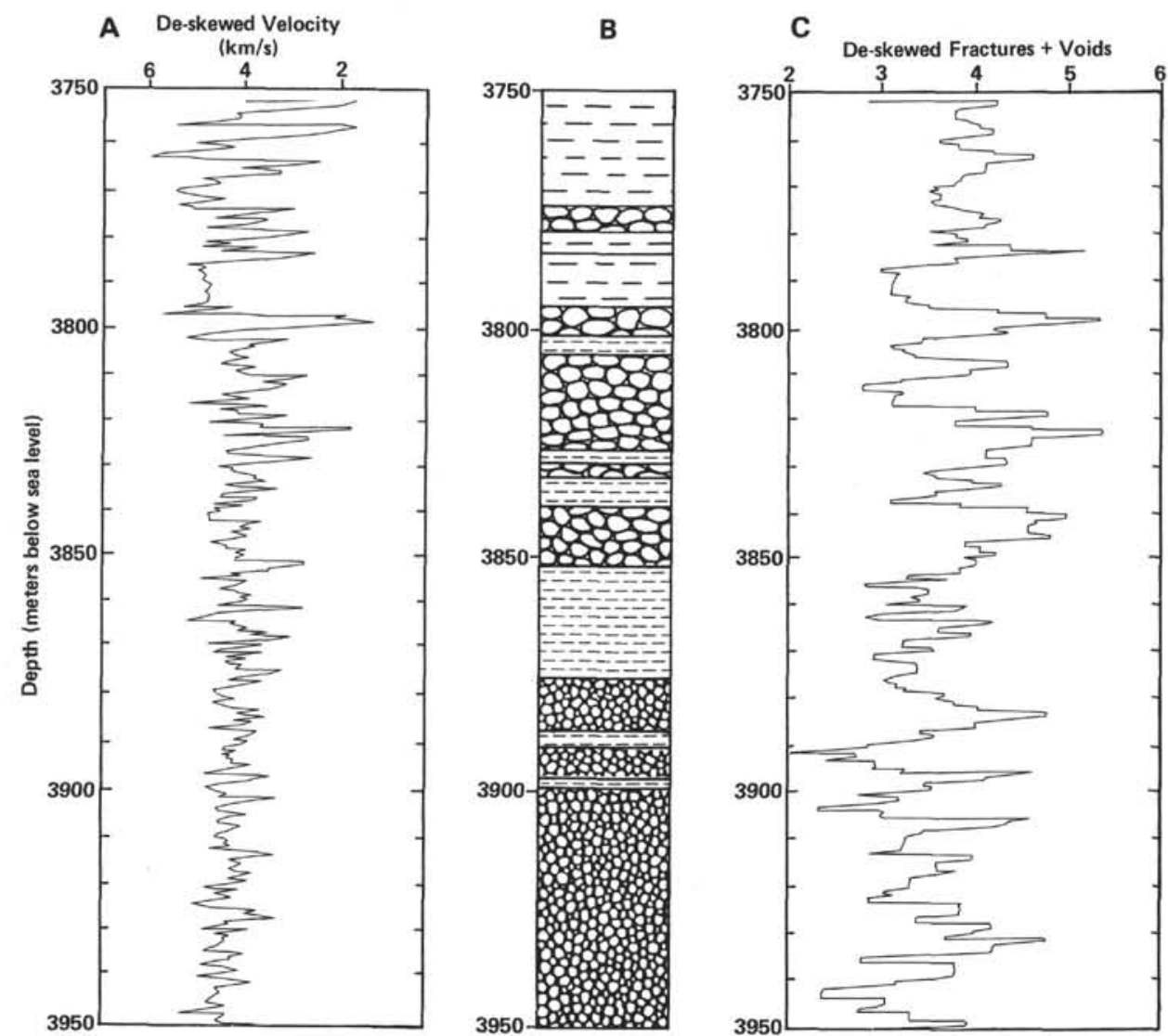

Figure 7. A. Data of Figure 5 replotted with average depth trend removed. B. BHTV structural types (large pillows, small pillows, thick flows, thin flows). C. Data of Figures $6 \mathrm{~B}$ and $6 \mathrm{C}$ with depth trend removed.

A plot of de-skewed fracture + void count versus $V_{\mathrm{p}}{ }^{2}$ is highly scattered, but a slight positive correlation does exist (Fig. 8). However, we felt that this correlation might vary with structural units, so we plotted deskewed fractures + voids versus $V_{\mathrm{p}}^{2}$ for each structural unit. Indeed, each unit has a distinctly different correlation relationship (though always positive) between deskewed fractures, voids, and $V_{\mathrm{p}}^{2}$ (Figs. 9 and 10). Recombining the total population, yet keeping separate structural units, produces a clearer understanding of how the de-skewed fractures and voids correlate with $V_{\mathrm{p}}^{2}$ down-hole in Hole 504B (Fig. 11).

The conclusion is that seismic velocity is decidedly lower in segments of the hole with fracture + void counts higher than 4.0 (an arbitrary scale, let us recall). Attempting to justify this conclusion, we return to the overall increase in velocity with depth into Layer 2A (Fig. 12), and see that the high fracture + void count population ( $>4.0$ in Fig. 11) of velocity points increases in sonic velocity from $\sim 3.2 \mathrm{~km} / \mathrm{s}$ to $\sim 5.2 \mathrm{~km} / \mathrm{s}$ with depth, whereas the low fracture + void count population $(<4.0$ in Fig. 11) increases only from $4.8 \mathrm{~km} / \mathrm{s}$ to $6.0 \mathrm{~km} / \mathrm{s}$, presumably reflecting the velocity in the solid basalt segments of the hole (Fig. 13). The increase in Layer 2A average velocity with depth thus appears to be caused mostly by changes in velocity in the high fracture/void segments of the hole (Fig. 13). Since sea water $\left(V_{\mathrm{p}}=1.5\right.$ $\mathrm{km} / \mathrm{s}$ ) replacement in cracks and voids with clays and zeolites $\left(V_{\mathrm{p}}=4 \mathrm{~km} / \mathrm{s}\right)$ would increase the velocity of a highly fractured basalt (Schreiber and Fox, 1977), we conclude that this hypothesis is the most likely explanation for the observed Layer 2A seismic-velocity increase with depth (an example of such infilling in cored basalts is shown in Fig. 14). It is not difficult to extrapolate this correlation to the proposal that increase in Layer $2 \mathrm{~A}$ velocity with age is also the result of replacement of sea water within cracks and voids with clays and zeolites as the oceanic crustal plumbing system clogs up with age.

The high scatter in this otherwise positive cross-correlation is probably caused by the poor resolving power of the Gearhart-Owen velocity logging tool used in Hole 504B. The source-receiver spacing was $60 \mathrm{~cm}$, barely sufficient to resolve velocities within centimeter-thick zones of intense fracturing or pillow rims.

\section{SUMMARY}

The existence of a weak but positive cross-correlation between zones with high fracture and void concentrations and the low-velocity troughs in the sonic-velocity $\log$ forms a constraint on the composition of the "filling" material in these fractures and voids. Through the BHTV, we can now say that the low-sonic-velocity troughs are "seeing into" these fractures and voids.

This leads to an extremely interesting advance in our knowledge of the cause of the long-observed increase in 


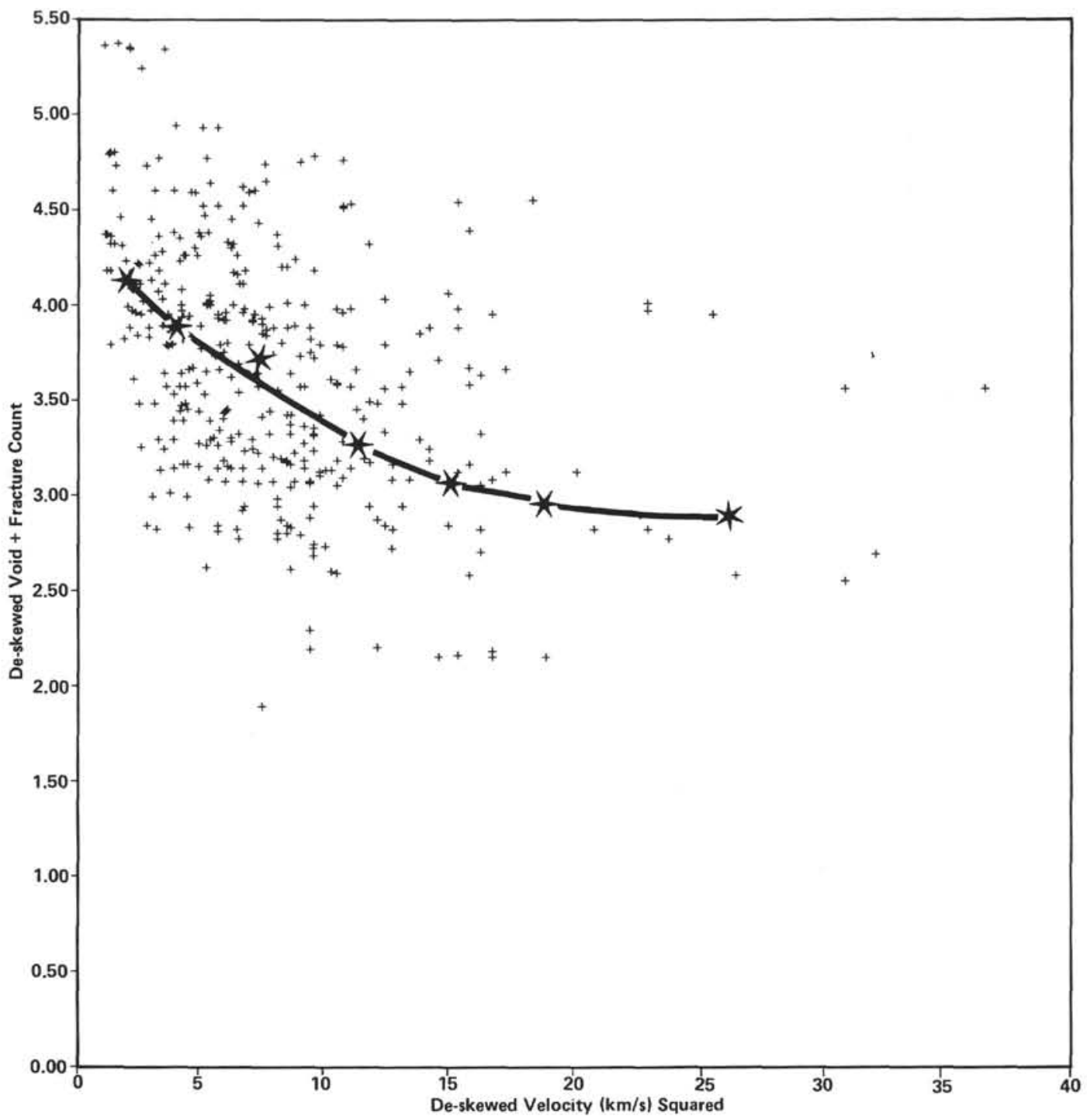

Figure 8. De-skewed void + fracture count versus de-skewed velocity squared. Stars are medians.

seismic velocity with depth from Layer $2 \mathrm{~A}$ velocities of 3 to $4 \mathrm{~km} / \mathrm{s}$ to Layer $2 \mathrm{~B}$ velocities $>5 \mathrm{~km} / \mathrm{s}$. Because laboratory measurements of compressional-wave velocity on basalts are consistently higher than observed seismic velocities in Layers $2 \mathrm{~A}$ and $2 \mathrm{~B}$, factors other than igneous mineralogy must cause the low velocities. Such factors as degree of alteration, crack geometry, and in situ pore pressure are known to affect seismic velocity (Fox and Stroup, 1981), but direct observations of the cause of the low velocity and its increase with depth in Layer 2 have not previously been possible.

We observe that sonic velocities in the low-velocity troughs, which correlate crudely with fractures and voids on a centimeter-scale in Hole 504B, increase from $3.0 \mathrm{~km} / \mathrm{s}$ at the top of Layer $2 \mathrm{~A}$ to $\sim 5.0 \mathrm{~km} / \mathrm{s} 200 \mathrm{me}-$ ters into the basaltic section. Such an increase in velocity with depth is not reflected in the low fracture + void regions of the hole (Fig. 13). Therefore, the general increase in average velocity with depth is not caused by a change within the "solid" basaltic units of Layer 2.
Instead, the increase in velocity in Layer 2 appears to be related to an increase in velocity of the material filling cracks and voids as we move deeper into the crust in Hole 504B. The proximity of velocities observed in the fractures and voids of the upper 80 to 100 meters of the section to that of sea water $\left(V_{\mathrm{p}}=1.5 \mathrm{~km} / \mathrm{s}\right)$ leads us to believe firmly that most cracks and voids are "open" and filled with sea water, rather than with low-temperature-alteration products of hydrothermal circulation, such as clay and zeolite. An average velocity of $3 \mathrm{~km} / \mathrm{s}$ indicates a ratio of 2:1 sea water to clay $\left(V_{\mathrm{p}}=4.0-5.0\right.$ $\mathrm{km} / \mathrm{s}$ ) in fractures and voids of the upper 100 meters of Layer $2 \mathrm{~A}$.

Similarly, the lower 100 meters or so of the Hole 504B section appears to have a much larger percentage of clay and zeolite filling cracks and voids, because the average velocity of low-velocity troughs correlated with fracture and opaque zones is $\sim 5 \mathrm{~km} / \mathrm{s}$; a ratio of $>3: 1$ clay to sea water is necessary. This conclusion is supported by the general increase in the amount of clay and 


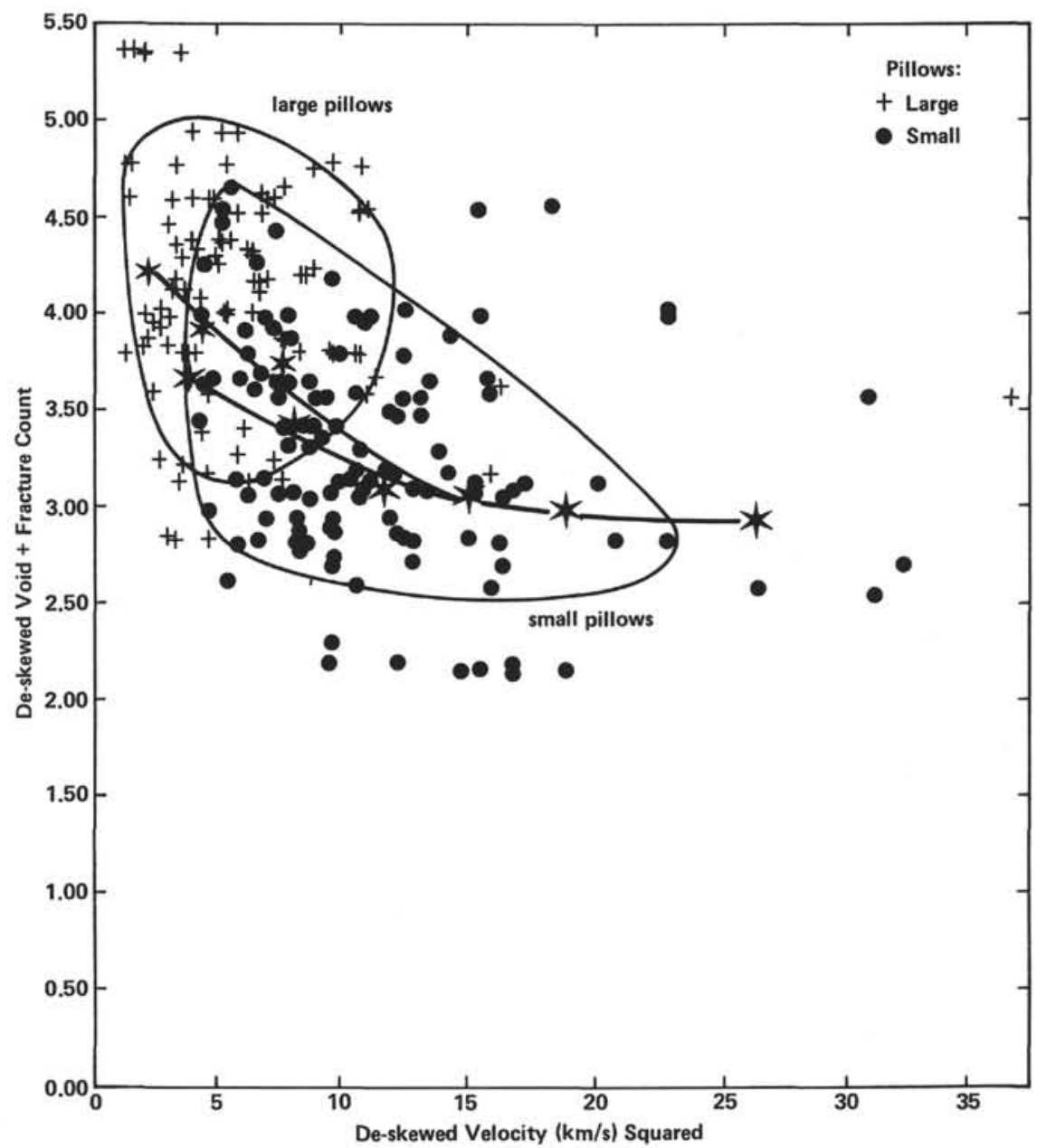

Figure 9. De-skewed void + fracture count versus de-skewed velocity squared, pillow units of Figure 7 only. Loops $85 \%$ of each data set. Other symbols as explained in preceding figures.

zeolites found in the cores recovered toward the bottom of Hole 504B drilled during Leg 69 (an additional $300+$ meters were cored in the hole during Leg 70) though core recovery was only $29 \%$ (CRRUST, in press).

Thus, the BHTV images form a powerful interpretive tool for determining geophysical and geological structure and stratigraphy of the oceanic crust when coupled with detailed velocity logging. However, the present sonic tools are barely adequate. Greater resolution and determination of variations in shear-wave and compressional-wave velocity on a centimeter scale are necessary to tie the BHTV imagery fully to the fine-scale structure of the oceanic crust.

\section{ACKNOWLEDGMENTS}

We wish to thank Bob Broding and the Amoco Oil Field Research Co. of Tulsa, Oklahoma, and Jerry Summers and the Simplec Manufacturing Co. of Dallas, Texas, for invaluable support throughout this project. Added support from Larry May and the Global Marine drilling crew made this project successful. This work was supported by the National Science Foundation under grant OCE-78-27026.

\section{REFERENCES}

Anderson, R. N., Langseth, M. G., and Sclater, J. G., 1977. The mechanisms of heat transfer through the floor of the Indian Ocean. J. Geophys. Res., 82:3391-3409.
Anderson, R. N., and Zoback, M. D, 1982. Permeability, under-pressures and convection in the oceanic crust of the Costa Rica Rift, Eastern Equatorial Pacific. J. Geophys. Res., 87:2860-2868.

Christensen, N. I., and Salisbury, M. H., 1972. Sea floor spreading, progressive alteration of layer 2 basalts and associated changes in seismic velocities. Earth Planet. Sci. Lett., 15:367-375.

1975. Structure and constitution of the lower oceanic crust. Rev. Geophys. Space Phys., 13:57-86.

CRRUST, in press. Deep sea drilling results of Legs $68 \mathrm{~A}, 69$ and 70 on the south flank of the Costa Rica Rift. Geol. Soc. Am. Bull.

Fox, P. J., Schreiber, E., and Petersen, J., 1973. The geology of the oceanic crust compressional wave velocities of oceanic rocks. $J$. Geophys. Res., 78:5155-5172.

Fox, P. J., and Stroup, J., 1981. The deep layers of the oceanic crust. In Emiliani, C. (Ed.), The Sea, (Vol. 7): New York (Wiley Interscience), 640-705.

Houtz, R. E., and Ewing, J., 1976. Upper crustal structure as a function of plate age. J. Geophys. Res., 81:2490-2498.

Hyndman, R. D., and Drury, M. J., 1976. The physical properties of basement rocks from deep sea drilling on the Mid-Atlantic Ridge. J. Geophys. Res., 81:4042-4059.

Schreiber, E., and Fox, P. J., 1976. Compressional wave velocities and mineralogy of fresh basalts from the FAMOUS area and the Oceanographer Fracture zone and the texture of layer $2 \mathrm{~A}$ of the oceanic crust. J. Geophys. Res., 81:4071-4076. 1977. Density and $P$-wave velocity of rocks from Famous region and their implication to the structure. Geol. Soc. Am. Bull., 88:600-608.

Spudich, P., and Orcutt, J., 1980. A new look at the seismic velocity structure of the oceanic crust. Rev. Geophys. Space Phys., 18: 627-645. 


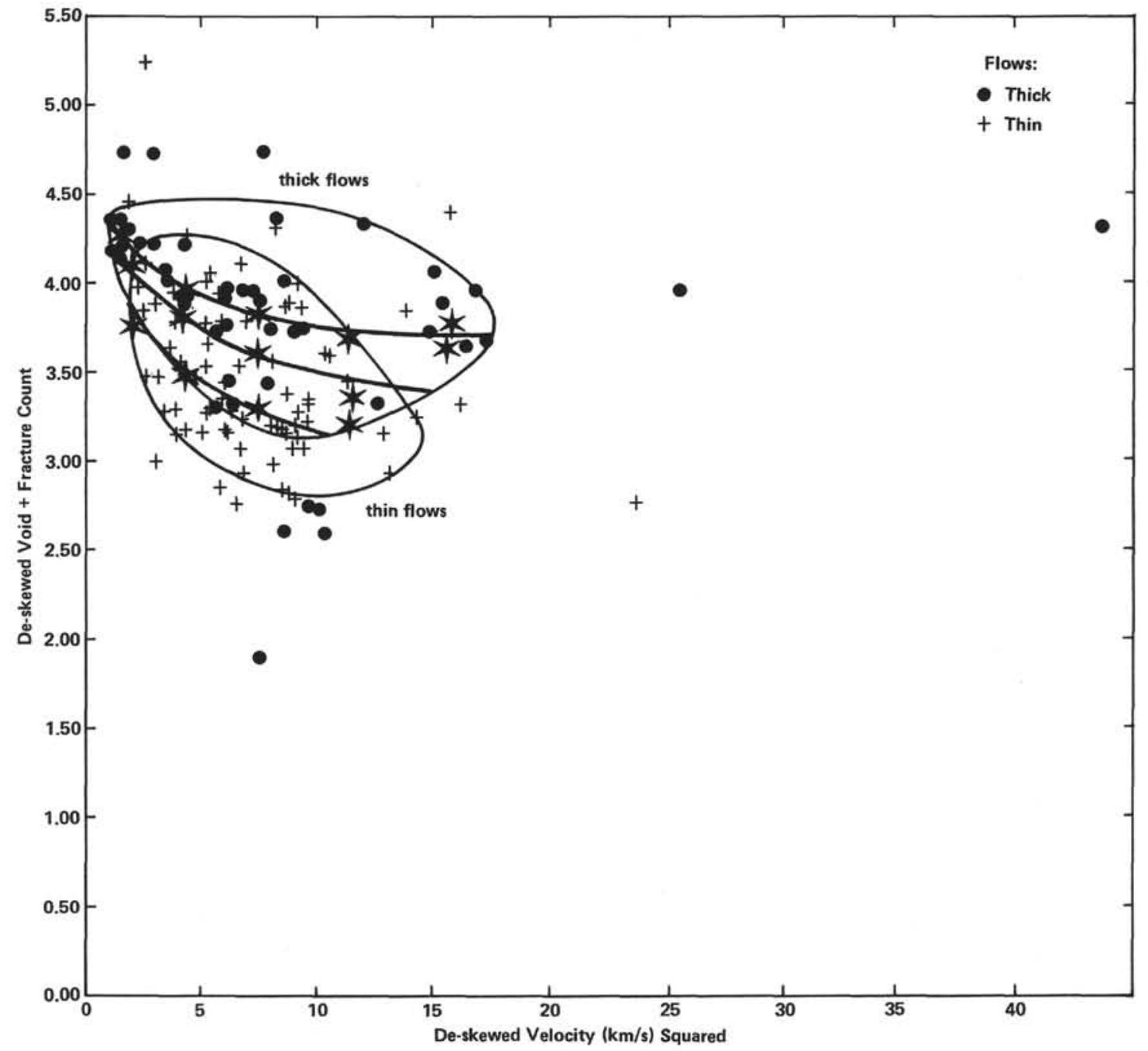

Figure 10. De-skewed void + fracture count versus de-skewed velocity squared, flow units of Figure 7B only. Symbols explained elsewhere. 


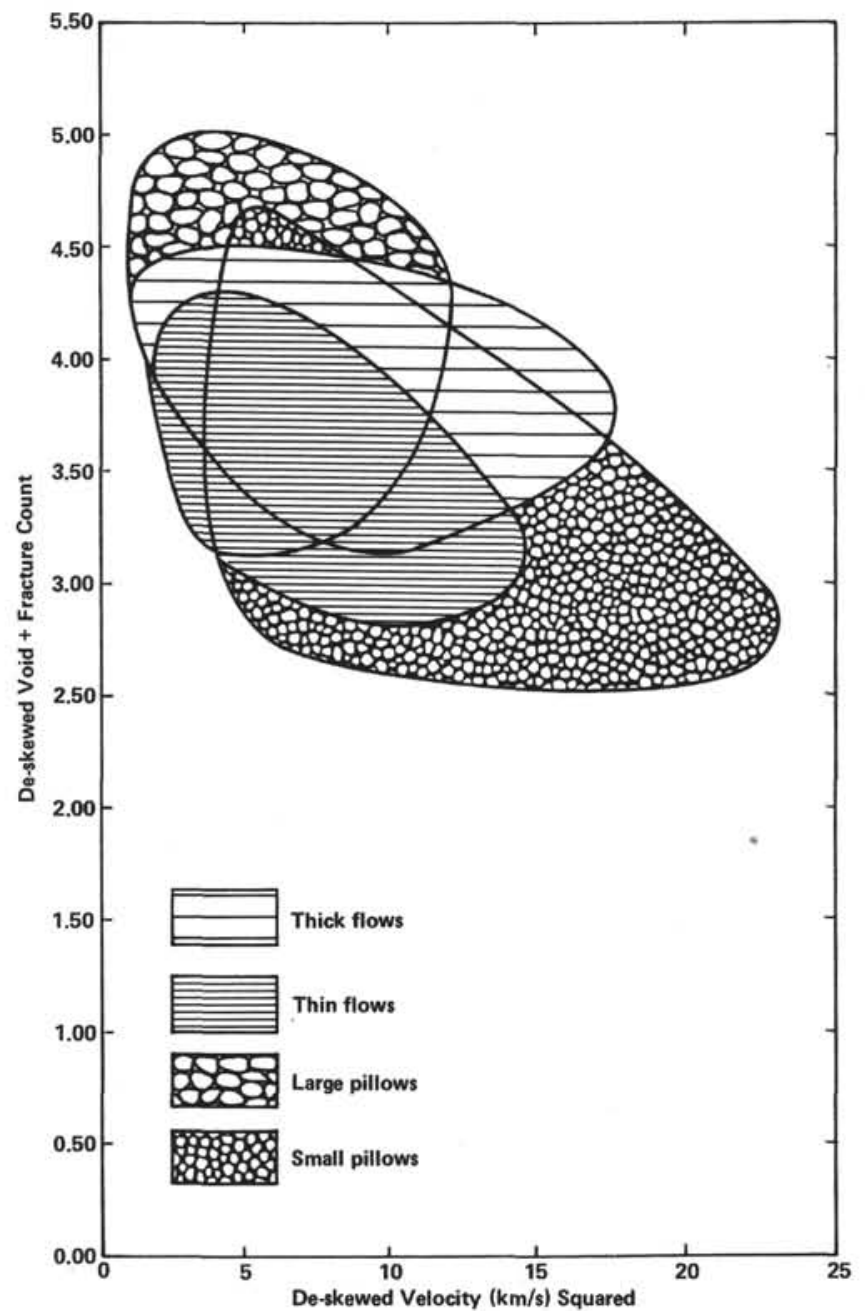

Figure 11. De-skewed fracture + void count versus de-skewed velocity: $85 \%$ percentile loops of each structure unit from Figures 9 and 10 . 


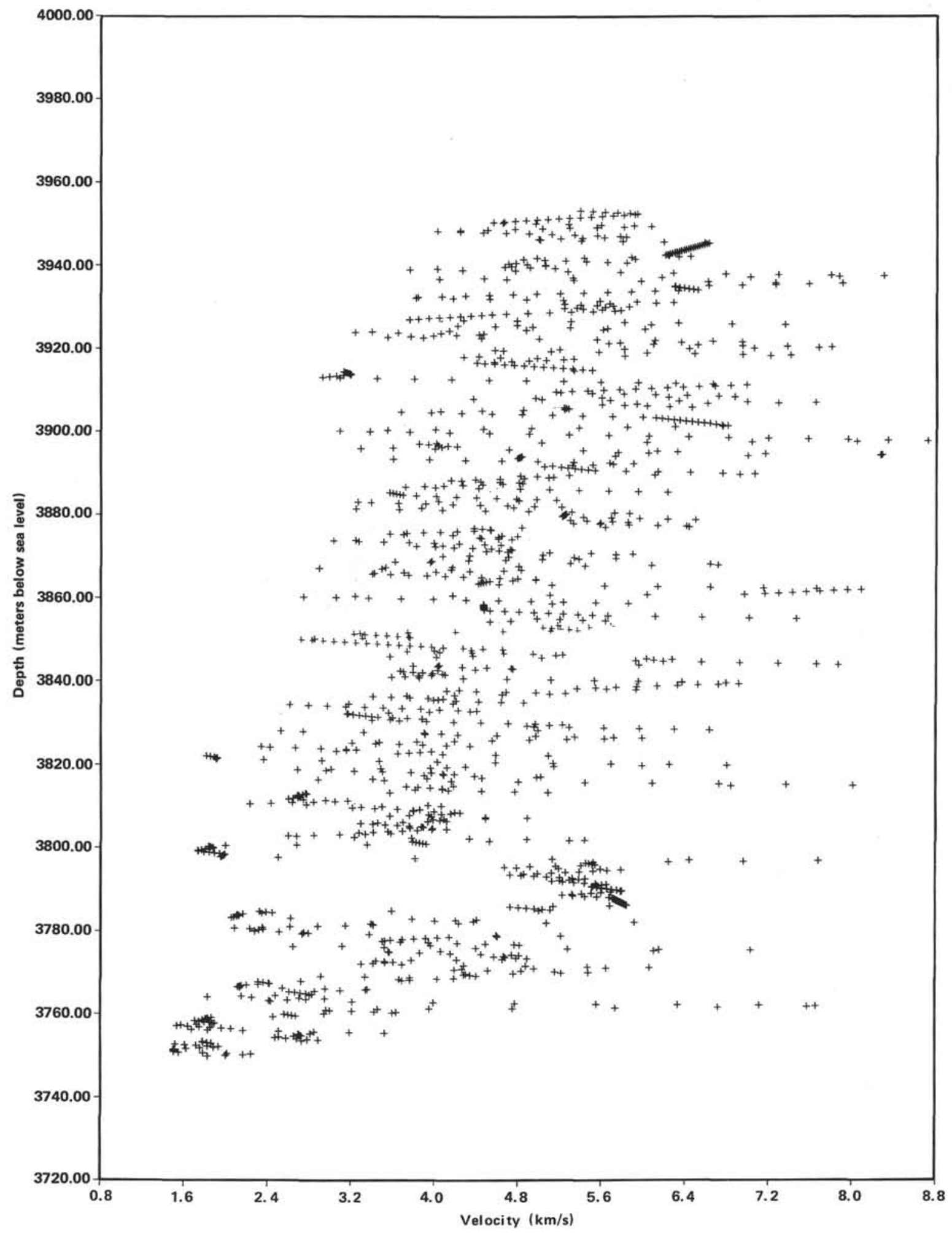

Figure 12. Plot of velocity versus depth from Figure 5. 


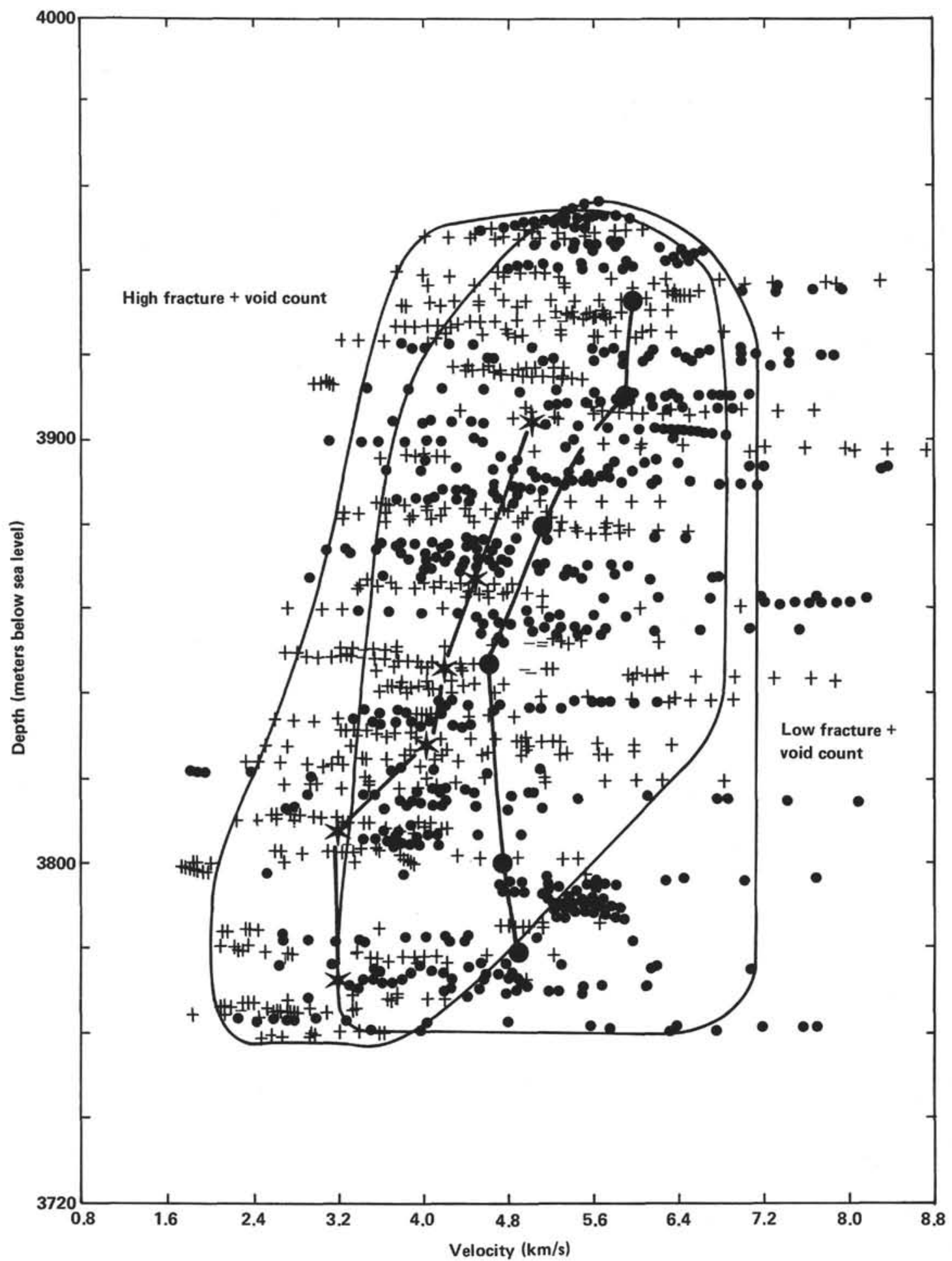

Figure 13. Plot of velocity versus depth for two data subsets of Figure 12: pluses are those with de-skewed fracture (void count $>4.0$ in Fig. 11), dots are those with fracture + void count $<4.0$. Other symbols as explained elsewhere. 

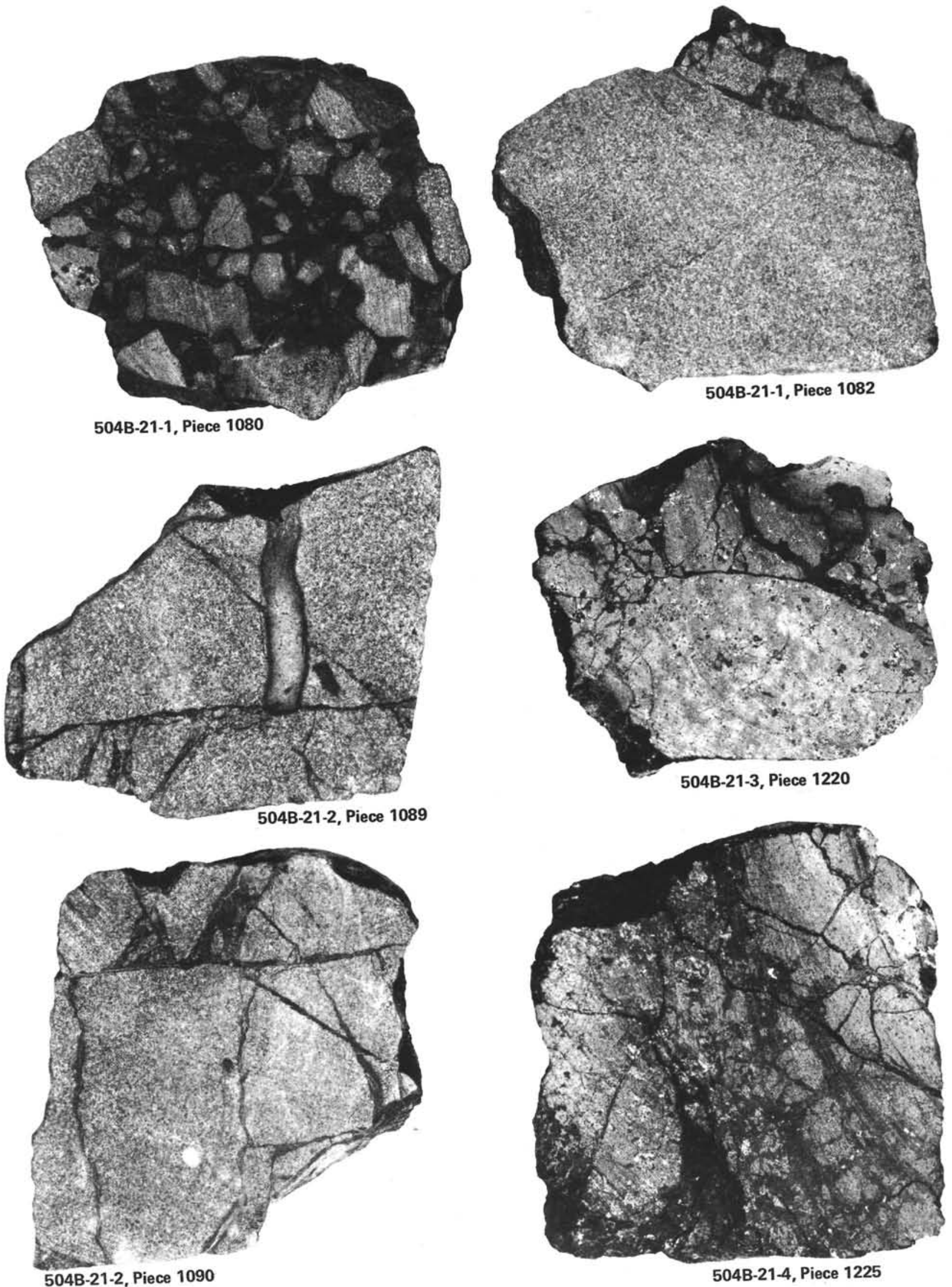

Figure 14. Examples of fracture and void filling seen in cores recovered from 3895 to 3904 meters depth in Hole 504B. All are tholeiitic basalt or basaltic breccia with clay and zeolite matrix. 